\title{
ANALISA DAN IMPLEMENTASI ALGORITMA TRIANGLE CHAIN PADA PENYANDIAN RECORD DATABASE
}

\author{
Taronisokhi Zebua \\ Staf Pengajar Program Studi Manajemen Informatika STMIK Budi Darma Medan \\ Jl. Sisingamangaraja No. 338 Simpang Limun Medan \\ Email : taronizeb@gmail.com
}

\begin{abstract}
Abstrak
Database merupakan data yang harus dijaga dan dipelihara oleh pemilik sistem informasi. Pemutakhiran informasi yang disajikan melalui sebuah sistem dapat dilakukan dengan adanya database. Sebuah database terdiri dari banyak record yang mengisi setiap field tabel yang telah tersedia di dalamnya. Record-record inilah yang nantinya akan menjadi informasi output yang disajikan kepada para pengguna sistem. Algoritma triangle chain merupakan salah satu algoritma penyandian yang beroperasi berdasarkan penyandian (kriptografi) klasik khususnya dalam teknik subtitusi terhadap karakter. Setiap karakter akan disubtitusi berdasarkan kunci dan faktor pengali yang telah ditetapkan berdasarkan formula yang berlaku dalam algoritma ini. Algoritma ini melakukan penyandian pada record sebanyak dua kali dan selalu bergantung pada hasil proses sebelumnya. Hal inilah yang mendasari rumitnya pemecahan dari algoritma penyandian berantai ini. Penyandian record database merupakan salah satu hal yang sangat penting dilakukan dalam meningkatkan keamanan database dari berbagai tingkat kejahatan yang dilakukan oleh orang-orang yang tidak berhak dan tidak bertanggungjawab. Implementasi algoritma triangle chain pada penyandian record database dapat mempersulit siapa saja yang berhasil mengakses dan mendapatkan database untuk memahami dan mengerti, merusak, mendistribusikan, mencuri database atau tindakan lain yang dapat merugikan pihak-pihak pemilik database.
\end{abstract}

Kata kunci : Record, Database, Kriptografi, Triangle Chain

\section{Pendahuluan}

Database secara umum merupakan susunan record data operasional lengkap dari suatu organisasi atau perusahaan, yang diorganisir dan disimpan di dalam media penyimpanan secara terintegrasi yang dapat dijadikan sebagai salah satu sumber dari setiap sistem informasi yang sedang berjalan sehingga mampu memenuhi informasi yang optimal yang dibutuhkan oleh para pengguna. Dengan adanya database, maka proses pemutakhiran informasi dapat dilakukan. Database dapat dibuat dengan menggunakan software yang ada seperti Microsoft SQL Server, Oracle, MySQL, Microsoft Access, dBase III, Paradox, FoxPro, dan lain-lain. Selanjutnya database dimaksud dapat diintegrasikan dengan aplikasi yang dibuat untuk melakukan beberapa operasi DBMS (Database Management System).

Sering sekali record yang tersimpan di dalam database masih persis sama dengan teks-teks yang ditampilkan sebagai informasi akhir bagi pengguna. Hal ini dapat mempermudah seorang kriptanalis maupun orang lain yang tidak mempunyai hak akses untuk dapat mengetahui secara langsung isi dari database tersebut serta dapat memberi peluang kepada mereka untuk melakukan pembocoran, mendistribusikan maupun melakukan modifikasi lain terhadap record database tersebut.

Algoritma triangle chain atau umumnya dikenal dengan sebutan algoritma rantai segitiga merupakan cipher yang ide awalnya dari algoritma kriptografi One Time Pad, yaitu kunci yang dibangkitkan secara random dan panjang kunci sepanjang plaintext yang akan dienkripsi. Pada algoritma kriptogarfi triagle chain ini pembangkitan kunci-kunci tersebut secara otomatis dilakukan dengan teknik berantai. Kekuatan cipher ini terletak pada kunci yaitu nilai integer yang menunjukkan pergeseran karakter-karakter sesuai dengan operasi pada caesar cipher. Kekuatan kedua terletak pada barisan bilangan-bilangan yang berfungsi sebagai pengali dengan kunci.

\section{Landasan Teori}

\subsection{Kriptografi}

Penjagaan sebuah informasi sangatlah diperlukan agar tidak jatuh ke tangan orang-orang yang tidak berhak untuk mengaksesnya. Teknik kriptografi telah banyak digunakan sebagai salah satu cara untuk menciptakan sebuah informasi yang selalu terjaga keabsahannya[1].

\subsubsection{Defenisi Kriptografi}

Kriptografi pada awalnya merupakan ilmu dan seni untuk menjaga kerahasiaan pesan dengan cara menyandikannya ke dalam bentuk yang tidak dapat dimengerti lagi maknanya. Kemudian seiring dengan berkembangnya kriptografi yaitu kriptografi tidak lagi 
sebatas mengenkripsikan pesan, tetapi juga memberikan aspek keamanan yang lain seperti serangan dari kriptanalisis. Oleh karena itu pengertian kriptografi pun berubah menjadi ilmu sekaligus seni untuk menjaga keamanan pesan.

Cryptography (kriptografi) berasal dari bahasa Yunani yaitu dari kata crypto yang berarti penulisan screet (rahasia), sedangkan graphein artinya writing (tulisan). Jadi secara sederhana dapat diartikan screet writing (tulisan rahasia). Definisi lain dari kriptografi adalah sebuah ilmu yang mempelajari teknik-teknik matematika yang berhubungan dengan aspek keamanan informasi seperti kerahasiaan, integritas data serta otentikasi[2].

Menurut terminologinya, kriptografi adalah ilmu dan seni untuk menjaga keamanan pesan ketika pesan dikirim dari suatu tempat ke tempat yang lain[1].

\subsubsection{Algoritma Kriptografi}

Algoritma kriptografi merupakan langkahlangkah logis bagaimana menyembunyikan pesan dari orang-orang yang tidak berhak atas pesan tersebut. Algoritma kriptografi terdiri dari tiga fungsi dasar[1] :

1. Enkripsi

Merupakan hal yang sangat penting dalam kriptografi, merupakan pengamanan data yang dikirim agar terjaga kerahasiaannya. Pesan asli disebut plaintext, yang diubah menjadi kode-kode yang tidak dimengerti. Enkripsi bisa diartikan sebagai cipher atau kode dengan menggunakan algoritma yang untuk mengkodekan data yang kita inginkan.

2. Dekripsi

Merupakan kebalikan dari proses enkripsi. Pesan yang telah dienkripsi dikembalikan ke bentuk asalnya (teks asli), disebut dengan dekripsi pesan. Algoritma yang digunakan untuk dekripsi tentu berbeda dengan algoritma yang digunakan untuk enkripsi.

3. Kunci

Kuci adalah kunci yang dipakai untuk melakukan enkripsi dan dekripsi. Kunci terbagi menjadi dua bagian, kunci rahasia (private key) dan kunci umum (public key).

Bedasarkan kunci yang dipakai dalam proses kriptografi, maka algoritma kriptografi dibagi menjadi[1]:

1. Algoritma Simetri

Algoritma ini sering disebut dengan algoritma klasik karena memakai kunci yang sama untuk kegiatan enkripsi dan dekripsi. Bila mengirim pesan dengan menggunakan algoritma ini, si penerima pesan harus diberitahu kunci dari pesan tersebut agar bisa mendekripsikan pesan yang dikirim. Keamanan dari pesan yang menggunakan algoritma ini tergantung pada kunci. Algoritma yang menggunakan kunci simteris misalnya DES,
Kode Rivest's, IDEA, AES, OTP, A5 dan lainlain.

2. Algoritma Asimetri

Algoritma asimetri sering juga disebut dengan algoritma kunci publik, dengan arti kata kunci yang digunakan untuk melakukan enkripsi dan dekripsi berbeda. Pada algoritma asimetri kunci terbagi menjadi dua bagian yaitu kunci umum (public key) yang bisa diketahui oleh umum dan kunci rahasia (private key) yaitu kunci yang dirahasiakan dan hanya boleh diketahui oleh satu orang saja.

\section{Fungsi Hash}

Fungsi hash sering disebut dengan fungsi has satu arah (one way function), message digest, fingerprint, fungsi kompresi dan Message Authentication Code (MAC) yang merupakan suatu fungsi matematika yang mengambil masukan panjang variabel dan mengubahnya ke dalam urutan biner dengan panjang yang tetap.

Algoritma kriptografi tersebut harus memiliki kekuatan untuk melakukannya[1]:

1. Konfusi/pembingungan (confusion), dari teks terang sehingga sulit untuk direkonstruksikan secara langsung tanpa menggunakan algoritma dekripsinya.

2. Difusi/peleburan (difusion), dari teks terang sehingga karakteristik dari teks terang tersebut hilang sehingga dapat digunakan untuk mengamankan informasi.

\subsubsection{Algoritma Kriptografi Klasik}

Sebelum komputer ada, kriptografi dilakukan dengan menggunakan pensil dan kertas. Algoritma kriptografi (cipher) yang digunakan saat itu, dinamakan juga algoritma klasik, adalah berbasis karakter, yaitu enkripsi dan dekripsi dilakukan pada setiap karakter pesan. Semua algoritma klasik termasuk ke dalam sistem kriptografi simetris dan digunakan jauh sebelum kriptografi kunci publik ditemukan.

Kriptogarfi klasik memiliki beberapa ciri[1]:

1. Berbasis karakter

2. Menggunakan pena dan kertas saja, belum ada computer

3. Termasuk ke dalam kriptografi kunci simetris.

Tiga alasan mempelajari algoritma klasik :

1. Memahami konsep dasar kriptografi

2. Dasar algoritma kriptografi modern

3. Memahami kelemahan sistem kode.

Pada dasarnya, algoritma kriptografi klasik dapat dikelompokkan ke dalam dua macam cipher, yaitu[1]:

1. Cipher substitusi (substitution cipher)

Di dalam cipher substitusi setiap unit plainteks diganti dengan satu unit ciphertext. Satu "unit" di isini berarti satu huruf, pasangan huruf atau dikelompokkan lebih dari dua huruf. Algoritma substitusi tertua yang diketahui adalah Caesar 
cipher yang digunakan oleh kaisar Romawi, Julius Caesar (sehingga dinamakan juga casear cipher), untuk mengirimakan pesan yang dikirimkan kepada gubernurnya.

2. Cipher transposisi (transposition cipher)

Pada cipher transposisi, huruf-huruf di dalam plainteks tetap saja, hanya saja urutannya diubah. Dengan kata lain algoritma ini melakukan transpose terhadap rangkaian karakter di dalam teks. Nama lain untuk metode ini adalah permutasi atau pengacakan (scrambling) karena transpose setiap karakter di dalam teks sama dengan mempermutasikan karakter-karkater tersebut.

\subsubsection{Algoritma Triangle Chain (Rantai Segitiga)}

Algoritma kriptografi triangle chain atau umumnya dikenal dengan sebutan rantai segitiga merupakan cipher yang ide awalnya dari algoritma kriptografi One Time Pad, yaitu kunci yang dibangkitkan secara random dan panjang kunci sepanjang plainteks yang akan dienkripsi. Tetapi pada algoritma kriptogarfi rantai segitiga pembangkitan kunci-kunci tersebut secara otomatis dengan teknik berantai.

Algoritma rantai segitiga ini memiliki aturan substitusi berdasar pada caesar cipher yaitu dengan pergeseran huruf-huruf. Kekuatan cipher ini terletak pada kunci yaitu nilai integer yang menunjukkan pergeseran karakter-karakter sesuai dengan operasi pada caesar cipher. Kekuatan kedua terletak pada barisan bilangan-bilangan yang berfungsi sebagai pengali dengan kunci. Barisan bilangan tersebut dapat berupa bilangan tertentu seperti deret bilangan ganjil, deret bilangan genap, deret fibonancci, deret bilangan prima, serta deret bilangan yang dapat dibuat sendiri[3].

Pada kenyataannya cipher substitusi segitiga tidak dibuat secara sederhana, tetapi dengan mengenkripsi ganda (mengenkripsi dua kali), jadi plainteks dienkripsi dengan cipher segitiga I, kemudian hasil enkripsi pertama dienkripsi kembali dengan cipher segitiga II yang arah segitiga II merupakan kebalikan arah segitiga I.

Untuk itu maka standar untuk cipher segitiga ini adalah cipher segitiga ganda yaitu cipher rantai segitiga yang melakukan enkripsi ganda, yaitu dengan membuat pola enkripsi pertama dengan mengerucut ke arah kanan dan enkripsi kedua mengerucut ke arah kiri.

Secara matematis pola enkripsi rantai segitiga dapat digambarkan dengan matriks $\mathrm{N} \times \mathrm{N}$ dengan $\mathrm{N}$ merupakan panjang plainteks yang akan dienkripsi dan operasi pada alfabet ASCII.

Matriks dilambangkan dengan $\mathrm{M}_{\mathrm{ij}}$, dengan $1 \leq \mathrm{i} \leq$ $\mathrm{N}$ dan $1 \leq \mathrm{j} \leq \mathrm{N}$, nilai integer kunci dengan $\mathrm{K}$, faktor pengali merupakan tabel integer R. Plainteks dengan $\mathrm{P}$ dimana $\mathrm{P}$ merupakan tabel plainteks dengan panjang
$\mathrm{N}$ yaitu $\mathrm{P}[\mathrm{N}]$

Berikut operasi matriks untuk proses enkripsi[3]:

1. Matriks enkripsi segitiga pertama

Untuk baris ke-1 :

$\mathrm{M}_{1 \mathrm{j}}=\mathrm{P}[\mathrm{j}]+(\mathrm{K} * \mathrm{R}[\mathrm{1}]) \bmod 256$

untuk baris ke-2 dan selanjutnya untuk nilai $\mathrm{j} \geq \mathrm{i}$ :

$\mathrm{M}_{\mathrm{ij}}=\mathrm{M}_{(\mathrm{i}-1) \mathrm{j}}+(\mathrm{K} * \mathrm{R}[\mathrm{i}]) \bmod 256$

sehingga nilai cipherteks yang diperoleh adalah :

$\mathrm{M}_{\mathrm{ij}}$ pada nilai $\mathrm{j}=(\mathrm{N}+\mathrm{i})-\mathrm{N}$.

2. Matriks enkripsi segitiga kedua

Nilai $P$ diperoleh dari nilai $M_{i j}$ pada $i=j$

Untuk baris ke-1 :

$\left.\mathrm{M}_{1 \mathrm{j}}=\mathrm{P}[\mathrm{j}]+\left(\mathrm{K}^{*} \mathrm{R}[1]\right)\right) \bmod 256$

untuk baris ke 2 dan selanjutnya untuk nilai $\mathrm{j} \leq$ $(\mathrm{N}+1)-\mathrm{i}$ :

$\left.\mathrm{M}_{\mathrm{ij}}=\mathrm{M}_{(\mathrm{i}-1) \mathrm{j}}+\left(\mathrm{K}^{*} \mathrm{R}[\mathrm{i}]\right)\right) \bmod 256$

sehingga nilai cipherteks yang diperoleh adalah :

$\mathrm{M}_{\mathrm{ij}}$ pada nilai $\mathrm{j}=(\mathrm{N}+1)-\mathrm{i}$.

Keterangan :

$\mathrm{P}=$ Plainteks

$\mathrm{N}=$ Jumlah karakter plainteks

$\mathrm{M}=$ Matriks penampung hasil penyandian

$\mathrm{K}=$ Kunci

$\mathrm{R}=$ Row (baris perkalian faktor pengali dengan

kunci)

$\mathrm{i}=$ Indeks faktor pengali

$\mathrm{j}=$ Indek karakter plainteks

Sedangkan untuk proses dekripsi merupakan kebalikan dari proses enkripsi Berikut operasi matriks untuk proses dekripsi (Mohamad Firda Fauzan.Studi dan Implementasi Chiper Subtitusi Rantai Segitiga. 12 Februari $2012 . \quad$ http:// informatika.stei.itb.ac.id/ rinaldi.munir/Kriptografi/20 06-2007/Makalah1 / Makalah1-088.pdf) :

1. Matriks dekripsi segitiga pertama operasinya merupakan kebalikan dari matriks enkripsi, jadi operasi ini kebalikan operasi matriks enkripsi segitiga kedua. Nilai $\mathrm{C}$ merupakan tabel dari cipherteks dengan panjang $\mathrm{N}$ yaitu $\mathrm{C}[\mathrm{N}]$.

Untuk baris ke-1, berlaku formula :

$\mathrm{j} \leq(\mathrm{N}+1)-\mathrm{i}$

$\left.\mathrm{M}_{1 \mathrm{j}}=\mathrm{C}[\mathrm{j}]-(\mathrm{K} * \mathrm{R}[1])\right) \bmod 256$

sedangkan untuk baris kedua dan selanjutnya dimana nilai $\mathrm{j} \geq \mathrm{i}$, berlaku formula : $\mathrm{M}_{\mathrm{ij}}=\left(\mathrm{M}_{(\mathrm{i}-1)}\right.$ $\mathrm{j}-\mathrm{K} *(\mathrm{R}[\mathrm{i}])) \bmod 256$.

sehingga nilai plainteks yang diperoleh adalah : $\mathrm{M}_{\mathrm{ij}}$ pada nilai $\mathrm{j}=(\mathrm{N}+\mathrm{i})$-i.

2. Matriks dekripsi segitiga kedua

Untuk baris pertama berlaku formula :

$\left.\mathrm{M}_{1 \mathrm{j}}=\mathrm{C}[\mathrm{j}]-(\mathrm{K} * \mathrm{R}[1])\right) \bmod 256$

sedangkan untuk baris kedua dan seterusnya nilai $\mathrm{j} \geq \mathrm{i}$, berlaku formula :

$\left.\mathrm{M}_{\mathrm{ij}}=\mathrm{C}_{[\mathrm{i}-1] \mathrm{j}}-(\mathrm{K} * \mathrm{R}[\mathrm{i}])\right) \bmod 256$.

nilai plainteks yang diperoleh adalah :

$\mathrm{M}_{\mathrm{ij}}$ pada nilai $\mathrm{j}=(\mathrm{N}+1)-\mathrm{i}$. 
sehingga nilai plainteks yang diperoleh adalah : $\mathrm{M}_{\mathrm{ij}}$ pada nilai $\mathrm{j}=(\mathrm{N}+\mathrm{i})-\mathrm{N}$.

Keterangan :

$\mathrm{C}=$ Cipherteks

$\mathrm{N}=$ Jumlah karakter cipherteks

$\mathrm{M}=$ Matriks penampung hasil cipher yang dijadikan sebagai plaintext

$\mathrm{K}=$ Kunci

$\mathrm{R}=$ Row (baris perkalian faktor pengali dengan kunci)

$\mathrm{i}=$ Indeks faktor pengali

$\mathrm{j}=$ Indek karakter cipherteks

\section{Analisa}

\subsection{Enkripsi Record Database}

Record yang disandikan merupakan record yang terdapat disetiap field tabel database yang telah dipilih sebelumnya. Langkah-langkah yang dilakukan pada proses enkripsi record mengikuti aturan-aturan yang berlaku pada algoritma triangle chain. Sebelum proses enkripsi record dilakukan, terlebih dahulu setiap karakter dari record harus dikonversi ke dalam bilangan desimal sesuai dengan nilai-nilai pada tabel ASCII. Hal kedua yang dilakukan adalah pembacaan nilai kunci dan pembentukan tabel faktor pengali selanjutnya proses enkripsi record dilakukan. Nilai kunci yang digunakan merupakan bilangan integer positif (bukan nol), serta barisan bilangan pengali dapat menggunakan bilangan integer asli atau bilangan tertentu seperti deret bilangan ganjil, deret bilangan genap, deret bilangan prima, serta deret bilangan yang dapat dibuat sendiri. Proses enkripsi record database sesuai dengan algoritma triangle chain dapat digambarkan seperti pada gambar 1:
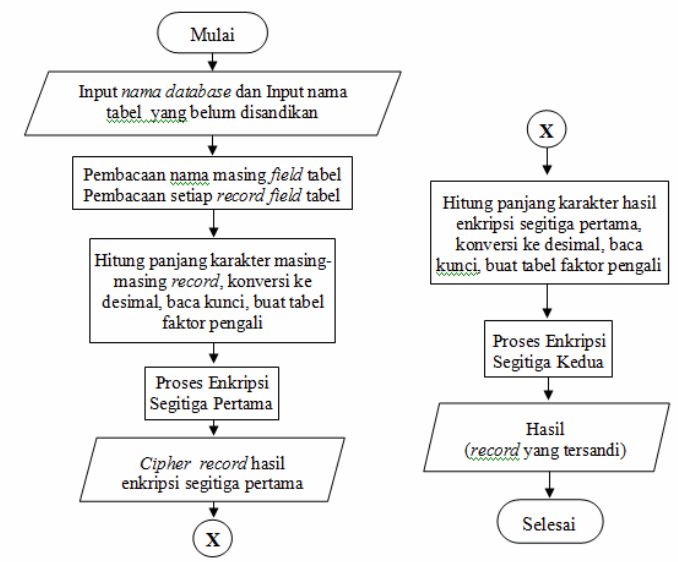

\section{Gambar 1 :Gambaran Umum Proses Penyandian Record Database}

Proses enkripsi dilakukan dengan dua tahap yaitu enkripsi segitiga pertama dan enkripsi segitiga ke dua, sehingga dihasilkan chiper akhir yang nantinya menjadi record database. Penyelesaian tahap enkripsi di atas dapat diuraikan melalui contoh kasus penyandian sebuah record di bawah ini :

3. Matriks enkripsi segitiga pertama

Plainteks adalah TARONI

Kunci adalah 3 (bilangan integer asli)

Faktor pengali dengan kunci adalah deret bilangan asli $(1,2,3, \ldots, n)$.

Langkah pertama yang dilakukan untuk proses enkripsi pertama ini adalah menentukan nilai desimal masing-masing karakter plainteks dalam ASCII :

$\begin{array}{llllll}\mathrm{T} & \mathrm{A} & \mathrm{R} & \mathrm{O} & \mathrm{N} & \mathrm{I} \\ 84 & 65 & 82 & 79 & 78 & 73\end{array}$

Langkah ke dua adalah membentuk tabel faktor pengali :

Seperti pada kasus di atas, maka faktor pengali yang diguanakan adalah deretan bilangan asli. Jumlah deret bilangan akan disesuaikan dengan jumlah banyaknya karakter dari plainteks.

Jadi, jumlah karakter plainteks (N) adalah 6 . Deret bilangan asli (R) yang menjadi faktor pengali adalah 1, 2, 3, 4, 5, 6 .

Langkah ke tiga adalah melakukan proses enkripsi segitiga pertama sesuai dengan formulanya.

$$
\begin{aligned}
& \text { Plainteks (P) = TARONI } \\
& \mathrm{N}=6 \\
& \mathrm{~K}=3 \\
& \mathrm{R}=1,2,3,4,5,6
\end{aligned}
$$

Untuk baris pertama $(i=1)$, maka :

$$
\begin{aligned}
\mathrm{M}_{11} & =(\mathrm{P}[1]+3 * \mathrm{R}[1]) \bmod 256 \\
& =(\mathrm{T}+3 *(1)) \bmod 256 \\
& =(84+3) \operatorname{Mod} 256 \\
& =87 \text { (huruf "W" dalam karakter }
\end{aligned}
$$

ASCII 256)

$\mathrm{M}_{12}=(\mathrm{P}[2]+3 * \mathrm{R}[1]) \bmod 256$

$=(\mathrm{A}+3 *(1)) \operatorname{Mod} 256$

$=(65+3) \operatorname{Mod} 256$

$=68$ (huruf "D" dalam karakter

ASCII 256)

$\mathrm{M}_{13}=(\mathrm{P}[3]+3 * \mathrm{R}[1]) \bmod 256$

$=(\mathrm{R}+3 *(1)) \operatorname{Mod} 256$

$=(82+3) \operatorname{Mod} 256$

$=85$ (huruf "U" dalam karakter

ASCII 256)

$\mathrm{M}_{14}=(\mathrm{P}[4]+3 * \mathrm{R}[1]) \bmod 256$

$=(\mathrm{O}+3 *(1)) \bmod 256$

$=(79+3) \operatorname{Mod} 256$

$=82$ (huruf "R" dalam karakter

ASCII 256)

$\mathrm{M}_{15}=(\mathrm{P}[5]+3 *(1)) \bmod 256$

$=(\mathrm{N}+3 *(1)) \bmod 256$

$=(78+3) \operatorname{Mod} 256$

$=81$ (huruf "Q" dalam karakter

ASCII 256)

$$
\begin{aligned}
\mathrm{M}_{16} & =(\mathrm{P}[6]+3 *(1)) \bmod 256 \\
& =(\mathrm{I}+3 *(1)) \bmod 256 \\
& =(73+3) \operatorname{Mod} 256 \\
& =76 \text { (huruf "L" dalam karakter }
\end{aligned}
$$


ASCII 256)

hasil sandi pada tahap $\mathrm{i}=1$ (baris pertama) adalah WDURQL.

Sampai pada tahap ini hasil penyandian dapat ditunjukkan di bawah ini :

TARONI (nilai desimal dalam ASCII : 846582 $797873) \rightarrow \mathrm{i}=0$

WDURQL (nilai desimal dalam ASCII : 8768 $85828176) \rightarrow \mathrm{i}=1$

Hasil penyandian baris pertama $(i=1)$ akan digunakan sebagai plainteks pada proses enkripsi baris ke dua $(i=2)$, dimana nilai $j \geq i$, sehingga : $\mathrm{i}=2, \mathrm{j}=2$

$$
\begin{aligned}
\mathrm{M}_{22} & =\left(\mathrm{M}_{(2-1) 2}+3 *(2)\right) \bmod 256 \\
& =\left(\mathrm{M}_{(1) 2}+3 *(2)\right) \bmod 256 \\
& =(\mathrm{D}+6) \bmod 256 \\
& =(68+6) \bmod 256 \\
& =74 \text { (huruf "J" dalam karakter }
\end{aligned}
$$

ASCII 256)

$$
\begin{aligned}
& \mathrm{M}_{23}=\left(\mathrm{M}_{(2-1) 3}+3 *(2)\right) \bmod 256 \\
& =\left(\mathrm{M}_{(1) 3}+3 *(2)\right) \bmod 256 \\
& =(85+6) \bmod 256 \\
& =91 \text { (huruf “[” dalam karakter }
\end{aligned}
$$
digunakan sebagai plainteks pada proses enkripsi baris ke tiga $(i=3)$, sehingga :
$=(88+9) \bmod 256$

$=97$ (huruf "a" dalam karakter

ASCII 256)

$\mathrm{M}_{35}=\left(\mathrm{M}_{(3-1) 5}+3 *(3)\right) \operatorname{Mod} 256$

$=\left(\mathrm{M}_{(2) 5}+3 *(3)\right) \operatorname{Mod} 256$

$=(87+9) \bmod 256$

$=96$ (huruf “" " dalam karakter

ASCII 256)

$\mathrm{M}_{36}=\left(\mathrm{M}_{(3-1) 6}+3 *(3)\right) \operatorname{Mod} 256$

$=\left(\mathrm{M}_{(2) 6}+3 *(3)\right) \operatorname{Mod} 256$

$=(82+9) \bmod 256$

$=91$ (huruf "[" dalam karakter

ASCII 256)

hasil dari enkripsi baris ke tiga $(\mathrm{i}=3)$ ini adalah da' $[$.

Hasil enkripsi sampai pada tahap baris ke tiga (i $=3$ ) dapat dilihat di bawah ini:

TARONI (dalam nilai ASCII 846582

$797873) \rightarrow \mathrm{i}=0$

WDURQL (dalam nilai ASCII $8768 \quad 85$

$828176) \rightarrow \mathrm{i}=1$

J [XWR (dalam nilai ASCII 7491

$888782) \rightarrow \mathrm{i}=2$

d a ` [ (dalam nilai ASCII

1009796

91) $\rightarrow \mathrm{i}=3$

Hasil enkripsi pada baris ke tiga $(i=3)$ akan digunakan sebagai plainteks pada proses enkripsi baris ke empat $(\mathrm{i}=4)$, sehingga :

$\mathrm{i}=4, \mathrm{j}=4$

$$
\begin{aligned}
\mathrm{M}_{44} & =\left(\mathrm{M}_{(4-1) 4}+3 *(4)\right) \operatorname{Mod} 256 \\
& =\left(\mathrm{M}_{(3) 4}+3 *(4)\right) \operatorname{Mod} 256 \\
& =(97+12) \bmod 256 \\
& =109 \text { (huruf "m" dalam karakter }
\end{aligned}
$$

ASCII 256)

$\mathrm{M}_{45}=\left(\mathrm{M}_{(4-1) 5}+3 *(4)\right) \operatorname{Mod} 256$

$=\left(\mathrm{M}_{(3) 5}+3 *(4)\right) \operatorname{Mod} 256$

$=(96+12) \bmod 256$

$=108$ (huruf "l" dalam karakter

ASCII 256)

$\mathrm{M}_{46}=\left(\mathrm{M}_{(4-1) 6}+3 *(4)\right) \operatorname{Mod} 256$

$=\left(\mathrm{M}_{(3) 6}+3 *(4)\right) \operatorname{Mod} 256$

$=(91+12) \bmod 256$

$=103$ (huruf "g" dalam karakter

ASCII 256)

hasil dari enkripsi baris ke tiga ini adalah mlg.

Hasil enkripsi sampai pada tahap baris ke empat (i $=4$ ) dapat dilihat di bawah ini:
TARONI
(dalam nilai ASCII $84 \quad 65$
$\begin{array}{llll}82 & 79 & 78 & 73) \rightarrow \mathrm{i}=0\end{array}$
WDURQL (dalam nilai ASCII $\quad 87 \quad 68$
$\begin{array}{llll}85 & 82 & 81 & 76)\end{array} \rightarrow \mathrm{i}=1$
J [XWR (dalam nilai ASCII
$\left.\begin{array}{llll}91 & 88 & 87 & 82\end{array}\right) \rightarrow \mathrm{i}=2$
d a ' [ (dalam nilai ASCII $\quad \mathbf{1 0 0} 97$
96 91) $\rightarrow \mathrm{i}=3$
mlg (dalam nilai ASCII
109
$108103) \rightarrow \mathrm{i}=4$
Hasil enkripsi pada baris ke empat $(\mathrm{i}=4)$ akan digunakan sebagai plainteks pada proses enkripsi 
baris ke lima $(i=5)$, sehingga :

$\mathrm{i}=5, \mathrm{j}=5$

$\begin{aligned} \mathrm{M}_{55} & =\left(\mathrm{M}_{(5-1) 5}+3 *(5)\right) \operatorname{Mod} 256 \\ & =\left(\mathrm{M}_{(4) 5}+3 *(5)\right) \operatorname{Mod} 256 \\ & =(108+15) \bmod 256 \\ & =123 \text { (huruf “\{ }\{\text { dalam karakter }\end{aligned}$

ASCII 256)

$\mathrm{M}_{56}=\left(\mathrm{M}_{(5-1) 6}+3 *(5)\right) \operatorname{Mod} 256$

$=\left(\mathrm{M}_{(4) 6}+3 *(5)\right) \operatorname{Mod} 256$

$=(103+15) \bmod 256$

$=118$ (huruf "v" dalam karakter

ASCII 256)

hasil dari enkripsi baris ke lima ini adalah $\{\mathrm{v}$.

Hasil enkripsi sampai pada tahap baris ke lima (i

=5) dapat dilihat di bawah ini:

TARONI (dalam nilai ASCII $84 \quad 65$

827978 73) $\rightarrow \mathrm{i}=0$

WDURQL (dalam nilai ASCII 8768

$\begin{array}{llll}85 & 82 & 81 & 76)\end{array} \rightarrow \mathrm{i}=1$

J [XWR (dalam nilai ASCII $\quad 74$

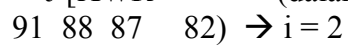

d a ` [ (dalam nilai ASCII $\quad \mathbf{1 0 0} 9787$

91) $\rightarrow \mathrm{i}=3$

$\mathrm{mlg} \quad$ (dalam nilai ASCII

$10999103) \rightarrow \mathrm{i}=4$ $\{\mathrm{v}$ (dalam nilai ASCII

$123118) \rightarrow \mathrm{i}=5$

Hasil enkripsi pada baris ke lima $(i=5)$ akan digunakan sebagai plainteks pada proses enkripsi baris ke enam ( $i=6)$, sehingga :

$\mathrm{i}=6, \mathrm{j}=6$

$\mathrm{M}_{66}=\left(\mathrm{M}_{(6-1) 6}+3 *(6)\right) \operatorname{Mod} 256$

$=\left(\mathrm{M}_{(5) 6}+3 *(6)\right) \operatorname{Mod} 256$

$=(118+18) \bmod 256$

$=136$ (huruf “ " " dalam karakter

ASCII 256)

hasil dari enkripsi baris ke tiga ini adalah ` .

Hasil enkripsi sampai pada tahap baris ke enam (i

=6) dapat dilihat di bawah ini:

TARONI

(dalam nilai ASCII 846582

$797873) \rightarrow \mathrm{i}=0$

WDURQL (dalam nilai ASCII 876885

$828176) \rightarrow \mathrm{i}=1$

J $[$ XWR

(dalam nilai ASCII $\quad \mathbf{7 4} 91$

$888782) \rightarrow \mathrm{i}=2$

d a ` [ (dalam nilai ASCII

1009787

91) $\rightarrow \mathrm{i}=3$

mlg (dalam nilai ASCII

109

$99103) \rightarrow \mathrm{i}=4$

$$
\text { a (dalam nilai }
$$

ASCII

114 118) $\rightarrow \mathrm{i}=5$

136) $\rightarrow \mathrm{i}=6$

$$
\text { (dalam nilai }
$$

ASCII

huruf pertama dari masing-masing baris sebanyak satu karakter sesuai dengan formula Mij pada nilai $\mathrm{j}=(\mathrm{N}+\mathrm{i})-\mathrm{N}$ akan menjadi chiperteks pada proses enkripsi segitiga pertama, sehingga :

TARONI plainteks

WDURQL hasil sandi pada $\mathrm{i}=1$ dan $\mathrm{j}=(6+1)-6$

$$
\begin{aligned}
& =1 \\
& \mathbf{J} \text { [XWRhasil sandi pada } \mathrm{i}=2 \text { dan } \mathrm{j}=(6+2)-6 \\
& =2 \\
& \text { d a ` [ hasil sandi pada } \mathrm{i}=3 \text { dan } \mathrm{j}=(6+3)-6 \\
& =3 \\
& \text { mlg hasil sandi pada } \mathrm{i}=4 \text { dan } \mathrm{j} \\
& =(6+4)-6=4 \\
& \{\mathrm{v} \quad \text { hasil sandi pada } \mathrm{i}=5 \text { dan } \mathrm{j} \\
& =(6+5)-6=5 \\
& =(6+6)-6=6 \\
& \text { hasil sandi pada } i=6 \text { dan } j
\end{aligned}
$$

maka yang menjadi cipher pada proses enkripsi

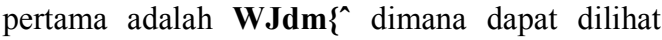
bahwa susunan dari baris dan kolomnya berbentuk segitiga yang mengerucut ke kiri.

4. Matriks enkripsi segitiga ke dua

Langkah-langkah yang dilakukan pada proses enkripsi segitiga kedua hampir sama dengan proses pada enkripsi segitiga pertama. Faktor pengali dan kunci yang digunakan tetap sama. Pada proses ini yang menjadi plainteks adalah cipher yang dihasilkan dari proses enkripsi segitiga pertama ( WJdm\{^) kemudian dienkrip lagi sesuai dengan formula yang berlaku pada proses enkripsi segitiga ke dua.

Plainteks $=\mathrm{W} \quad \mathrm{J} \quad \mathrm{d} \quad \mathrm{m} \quad\{\wedge$ (cipher hasil enkripsi segitiga pertama)

$$
\begin{array}{lllllll}
87 & 74 & 100 & 109 & 123 & 136 & \text { (nilai }
\end{array}
$$
desimal dalam ASCII)

Untuk baris pertama $(\mathrm{i}=1)$ :

$$
\begin{aligned}
\mathrm{M}_{11} & =(\mathrm{P}[1]+(3 * 1)) \bmod 256 \\
& =(\mathrm{W}+(3 * 1)) \bmod 256 \\
& =(87+3) \bmod 256 \\
& 90 \text { (huruf "Z" dalam karakter } \\
\text { ASCII 256) } & \\
\mathrm{M}_{12} & (\mathrm{P}[2]+(3 * 1)) \bmod 256 \\
& =(\mathrm{J}+(3 * 1)) \bmod 256 \\
& =(74+3) \bmod 256 \\
& =77 \text { (huruf "M" dalam karakter }
\end{aligned}
$$

ASCII 256)

$\mathrm{M}_{13}=(\mathrm{P}[3]+(3 * 1)) \bmod 256$

$=(\mathrm{d}+(3 * 1)) \bmod 256$

$=(100+3) \bmod 256$

$=103$ (huruf "g" dalam karakter

ASCII 256)

$\mathrm{M}_{14}=(\mathrm{P}[4]+(3 * 1)) \bmod 256$

$=(\mathrm{m}+(3 * 1)) \bmod 256$

$=(109+3) \bmod 256$

$=112$ (huruf " $p$ " dalam karakter

ASCII 256)

$\mathrm{M}_{15}=(\mathrm{P}[5]+(3 * 1)) \bmod 256$

$=(\{+(3 * 1)) \bmod 256$

$=(123+3) \bmod 256$

$=126$ (huruf “ " dalam karakter

ASCII 256)

$\mathrm{M}_{16}=(\mathrm{P}[6]+(3 * 1)) \bmod 256$

$=\left({ }^{\wedge}+(3 * 1)\right) \bmod 256$

$=(136+3) \bmod 256$

= 139 (huruf " " " dalam karakter 
ASCII 256)

hasil dari enkripsi baris pertama $(i=1)$ adalah ZMgp < .

Hasil enkripsi sampai pada tahap baris pertama (i =1) dapat dilihat di bawah ini:

W J d m \{^(87 $74 \begin{array}{lllll}87 & 100 & 109 & 123 & 136\end{array}$ Z $\quad$ M g p $\sim$ < ( ( $\begin{array}{llllll}90 & 77 & 103 & 112 & 126 & 139\end{array}$

Hasil enkripsi baris pertama $(i=1)$ akan digunakan sebagai plainteks pada proses enkripsi baris ke dua dimana nilai $\mathrm{j} \leq(\mathrm{N}+1)-\mathrm{i}$, sehingga

$$
\begin{aligned}
\mathrm{i}=2 ; \mathrm{j} \leq & (6+1)-2 \rightarrow \mathrm{j} \leq 5 \\
\mathrm{M}_{21} & =\left(\mathrm{M}_{(2-1) 1}+(\mathrm{K} * \mathrm{R}[\mathrm{i}])\right) \bmod 256 \\
& =\left(\mathrm{M}_{(1) 1}+(\mathrm{K} * \mathrm{R}[\mathrm{i}])\right) \bmod 256 \\
& =(\mathrm{Z}+(3 * 2)) \bmod 256 \\
& =(90+6) \bmod 256 \\
& =96 \text { (huruf “' " dalam karakter }
\end{aligned}
$$

ASCII 256)

$$
\begin{aligned}
& \mathrm{M}_{22}=\left(\mathrm{M}_{(2-1) 2}+(\mathrm{K} * \mathrm{R}[\mathrm{i}])\right) \bmod 256 \\
& =\left(\mathrm{M}_{(1) 2}+(\mathrm{K} * \mathrm{R}[\mathrm{i}])\right) \bmod 256 \\
& =(\mathrm{M}+(3 * 2)) \bmod 256 \\
& =(77+6) \bmod 256 \\
& =83 \text { (huruf "S" dalam karakter }
\end{aligned}
$$

Hasil enkripsi baris ke dua $(\mathrm{i}=2)$ akan digunakan sebagai plainteks pada proses enkripsi baris ke tiga, sehingga :

$\mathrm{i}=3 ; \mathrm{j} \leq(6+1)-3 \rightarrow \mathrm{j} \leq 4$

$$
\begin{aligned}
\mathrm{M}_{31} & =\left(\mathrm{M}_{(3-1) 1}+(\mathrm{K} * \mathrm{R}[\mathrm{i}])\right) \bmod 256 \\
& =\left(\mathrm{M}_{(2) 1}+(\mathrm{K} * \mathrm{R}[\mathrm{i}])\right) \bmod 256 \\
& =\left({ }^{+}(3 * 3)\right) \bmod 256 \\
& =(96+9) \bmod 256
\end{aligned}
$$

ASCII 256)

$=105$ (huruf “ $\mathrm{i}$ ” dalam karakter

$$
\begin{aligned}
\mathrm{M}_{32} & =\left(\mathrm{M}_{(3-1) 2}+(\mathrm{K} * \mathrm{R}[\mathrm{i}])\right) \bmod 256 \\
& =\left(\mathrm{M}_{(2) 2}+(\mathrm{K} * \mathrm{R}[\mathrm{i}])\right) \bmod 256 \\
& =(\mathrm{S}+(3 * 3)) \bmod 256 \\
\rightarrow \mathrm{i} & =0(83+9) \bmod 256 \\
\rightarrow \mathrm{i} & =192 \text { (huruf “ } \backslash \text { " dalam karakter }
\end{aligned}
$$
ASCII 256)

$$
\begin{aligned}
\mathrm{M}_{33} & \left(\mathrm{M}_{(3-1) 3}+(\mathrm{K} * \mathrm{R}[\mathrm{i}])\right) \bmod 256 \\
& =\left(\mathrm{M}_{(2) 3}+(\mathrm{K} * \mathrm{R}[\mathrm{i}])\right) \bmod 256 \\
& =(109+9) \bmod 256 \\
& =118 \text { (huruf “ } \mathrm{v} \text { " dalam karakter } \\
\text { ASCII 256) } & \\
\mathrm{M}_{34} & \left(\mathrm{M}_{(3-1) 4}+(\mathrm{K} * \mathrm{R}[\mathrm{i}])\right) \bmod 256 \\
& =\left(\mathrm{M}_{(2) 4}+(\mathrm{K} * \mathrm{R}[\mathrm{i}])\right) \bmod 256 \\
& =(\mathrm{V}+(3 * 3)) \bmod 256 \\
& =(118+9) \bmod 256 \\
& =127(\text { huruf “ } \square \text { " dalam karakter }
\end{aligned}
$$

hasil dari enkripsi baris ke tiga $(i=3)$ adalah $i \backslash v$ $\square$.

Hasil enkripsi sampai pada tahap baris ke tiga $(i=$ 3) dapat dilihat di bawah ini:

W J d $\mathrm{m}\{$ 个

$$
\begin{aligned}
& \mathrm{Z} \mathrm{M} \mathrm{g} \mathrm{p} \sim \quad \rightarrow 90 \quad 77 \quad 103 \\
& 112126139 \rightarrow \mathrm{i}=1 \\
& \text { S } \mathrm{S} \mathrm{V} \mathrm{V} \mathrm{,} \rightarrow 96 \quad 83 \quad 109 \quad 118 \quad 132 \\
& \mathrm{i} \backslash \mathrm{v} \square \quad \rightarrow \quad 105 \quad 92 \quad 118 \\
& 127 \rightarrow \mathrm{i}=3
\end{aligned}
$$

Hasil enkripsi baris ke tiga (i=3) akan digunakan sebagai plainteks pada proses enkripsi baris ke empat, sehingga :

$$
\begin{aligned}
\mathrm{i}=4 ; \mathrm{j} \leq & (6+1)-4 \rightarrow \mathrm{j} \leq 3 \\
\mathrm{M}_{41} & =\left(\mathrm{M}_{(4-1) 1}+(\mathrm{K} * \mathrm{R}[\mathrm{i}])\right) \bmod 256 \\
& =\left(\mathrm{M}_{(3) 1}+(\mathrm{K} * \mathrm{R}[\mathrm{i}])\right) \bmod 256 \\
& =(\mathrm{i}+(3 * 4)) \bmod 256 \\
& =(105+12) \bmod 256 \\
& =117 \text { (huruf “ } \mathrm{u} \text { " dalam karakter } \\
\text { ASCII 256) } & \\
\mathrm{M}_{42} & \left(\mathrm{M}_{(4-1) 2}+(\mathrm{K} * \mathrm{R}[\mathrm{i}])\right) \bmod 256 \\
& =\left(\mathrm{M}_{(3) 2}+(\mathrm{K} * \mathrm{R}[\mathrm{i}])\right) \bmod 256 \\
& =(\backslash+(3 * 4)) \bmod 256 \\
& =(92+12) \bmod 256 \\
& =104(\text { huruf “ } \mathrm{h} \text { " dalam karakter }
\end{aligned}
$$

ASCII 256)

$$
\begin{aligned}
\mathrm{M}_{43} & =\left(\mathrm{M}_{(4-1) 3}+(\mathrm{K} * \mathrm{R}[\mathrm{i}])\right) \bmod 256 \\
& \Rightarrow \mathrm{i}\left(\mathrm{NO}_{(3) 3}+(\mathrm{K} * \mathrm{R}[\mathrm{i}])\right) \bmod 256 \\
& =(\mathrm{v}+(3 * 4)) \bmod 256 \\
& =(118+12) \bmod 256 \\
& \Rightarrow \mathrm{i} \neq 32 \text { (huruf “, " dalam karakter }
\end{aligned}
$$

ASCII 256)

hasil dari enkripsi baris ke empat $(i=4)$ adalah uh, .

Hasil enkripsi sampai pada tahap baris ke empat (i =4) dapat dilihat di bawah ini:

W J d $\mathrm{m}\{$

$\mathrm{Z} \mathrm{M} \mathrm{g} \mathrm{p} \mathrm{\sim} \quad \rightarrow 90 \quad 77 \quad 103$ $112126139 \rightarrow \mathrm{i}=1$ 


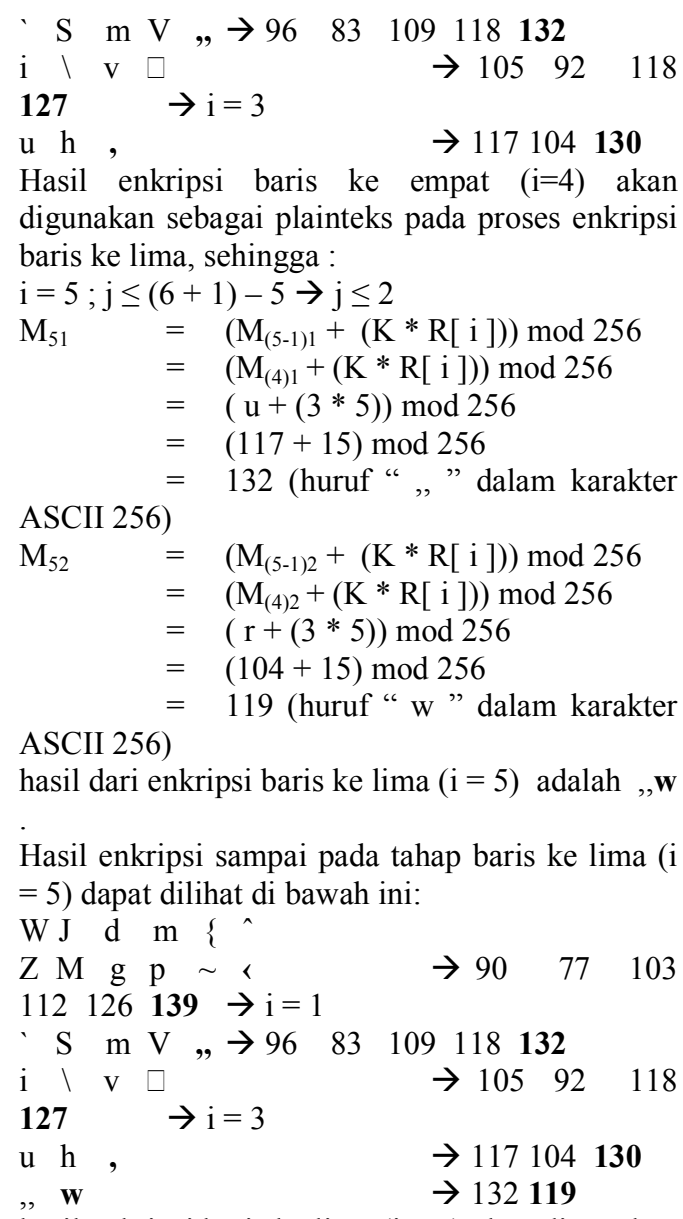

hasil enkripsi baris ke lima $(i=5)$ akan digunakan sebagai plainteks pada proses enkripsi baris ke enam, sehingga :

$\mathrm{i}=6 ; \mathrm{j} \leq(6+1)-6 \rightarrow \mathrm{j} \leq 1$

$\mathrm{M}_{61}=\left(\mathrm{M}_{(6-1) 1}+(\mathrm{K} * \mathrm{R}[\mathrm{i}])\right) \bmod 256$

$=\left(\mathrm{M}_{(5) 1}+(\mathrm{K} * \mathrm{R}[\mathrm{i}])\right) \bmod 256$

$=(,,+(3 * 6)) \bmod 256$

$=(132+18) \bmod 256$

$=150$ (huruf “ - " dalam karakter

ASCII 256)

hasil dari enkripsi baris ke enam $(i=6)$ adalah -

Hasil enkripsi sampai pada tahap baris ke enam (i =6) dapat dilihat di bawah ini:

W J d $m\{$ ?

$\mathrm{Z}$ M g p $\sim$,

$\rightarrow 90 \quad 77 \quad 103$

$112126139 \rightarrow \mathrm{i}=1$

. $\mathrm{S} \quad \mathrm{m} \mathrm{V}, \rightarrow 96 \quad 83 \quad 109 \quad 118 \quad \mathbf{1 3 2}$

$\mathrm{i} \backslash \mathrm{V} \square \quad \rightarrow 105 \quad 92 \quad 118$

$127 \rightarrow \mathrm{i}=3$

$\mathrm{u} \mathrm{h}$,

$\rightarrow 117104 \mathbf{1 3 0}$

, $\mathbf{w}$

$\rightarrow 132119$

$\rightarrow 150$

karakter yang menjadi hasil enkrip segitiga kedua adalah huruf terakhir dari masing-masing baris dan diperoleh berdasarkan formula $M_{i j}$ pada nilai $\mathrm{j}=(\mathrm{N}+1)-\mathrm{i}$, sehingga :

$$
\begin{aligned}
& \text { Z M g p } \rightarrow \text { i }=\ll 2 \quad \rightarrow \mathrm{i}=1 \text { dan } \mathrm{j}=(6 \\
& +1)-1=6 \rightarrow \text { < } \\
& \text { S } m \text { V }, \rightarrow \mathrm{i}=2 \text { dan } \mathrm{j}=(6+1)-2=5 \rightarrow \\
& \rightarrow \mathrm{i}=4 \\
& \text { i } \backslash \mathrm{v} \square \quad \rightarrow \mathrm{i}=3 \text { dan } \mathrm{j}=(6 \\
& +1)-3=4 \rightarrow \\
& \mathrm{u} \text { r, } \\
& +1)-4=3 \rightarrow \text {, } \\
& \text {, w } \\
& +1)-5=2 \rightarrow \mathrm{W} \\
& \rightarrow \mathrm{i}=4 \text { dan } \mathrm{j}=(6 \\
& \rightarrow \mathrm{i}=5 \text { dan } \mathrm{j}=(6 \\
& \rightarrow \mathrm{i}=6 \text { dan } \mathrm{j}=(6
\end{aligned}
$$$$
+1)-6=1 \rightarrow-
$$

Dapat dilihat bahwa hasil penyandian pada proses enkripsi segitiga kedua membentuk segitiga yang mengerucut ke kanan dan menghasilkan cipherteks akhir adalah $-\mathbf{w}, \square, \longleftrightarrow$. Cipher terakhir inilah yang nantinya disimpan menjadi record di dalam database.

\subsection{Dekripsi Record Database}

Proses dekripsi merupakan kebalikan dari proses enkripsi record database yang telah dilakukan sebelumnya. Kunci dan faktor pengali yang digunakan tetap sama septriti pada proses enkripsi. Proses dekripsi record database diawali pemilihan nama database kemudian memilih tabel yang telah dienkripsi. Semua recard tabel yang telah dipilih akan dikembalikan ke teks record semula (sebelum dienkripsi).

Proses dekripsit irectrd database sesuai dengan algoritma triangłei ehsiin dapat digambarkan seperti pada gambar 2 .

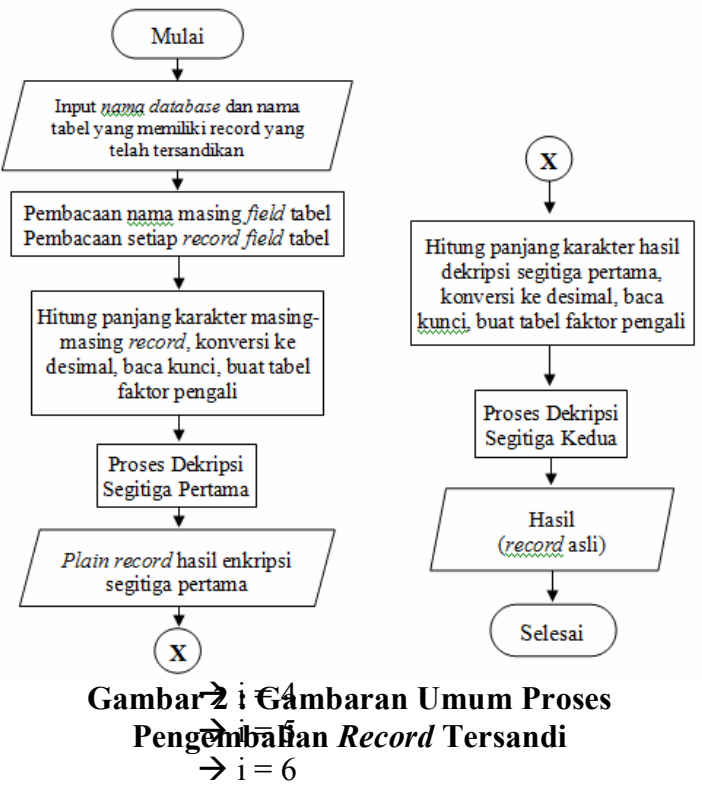

Proses pengembalian record tersandi ke record asli dilakukan sebanyak dua kali, terdiri dari dekripsi segitiga pertama dan dekripsi segitiga kedua. Penyelesaian tahap dekripsi di atas dapat diuraikan 
melalui contoh kasus di bawah ini dimana record sandi adalah hasil akhir dari penyandian contoh enkripsi :

1. Dekripsi segitiga pertama

chipertext adalah - w , $\square$, pada $\mathrm{i}=0$

$150119130127 \quad 132$

139 (nilai desimal dalam ASCII)

$$
\begin{array}{rl}
\mathrm{i}=1 & \mathrm{j} \leq(6+1)-1 \\
& \mathrm{j} \leq 6 \\
\mathrm{M}_{11} & \mathrm{C}[1]-(3 *[1])) \bmod 256 \\
& =(--(3 * 1)) \bmod 256 \\
& (150-3) \bmod 256 \\
= & 147 \text { (huruf “ " " dalam karakter }
\end{array}
$$

ASCII 256)

$$
\begin{aligned}
\mathrm{M}_{12} & =\mathrm{C}[2]-(3 *[1])) \bmod 256 \\
& =(\mathrm{w}-(3 * 1)) \bmod 256 \\
& =(119-3) \bmod 256 \\
& =116 \text { (huruf " } \mathrm{t} \text { " dalam karakter }
\end{aligned}
$$

ASCII 256)

$$
\begin{aligned}
\mathrm{M}_{13} & =\mathrm{C}[3]-(3 *[1])) \bmod 256 \\
& =(,-(3 * 1)) \bmod 256 \\
& =(130-3) \bmod 256 \\
& =127 \text { (huruf " } \square \text { " dalam karakter }
\end{aligned}
$$

Hasil dekripsi sampai pada tahap baris pertama (i =1) dapat dilihat di bawah ini :

$$
\begin{aligned}
& -\mathbf{w}, \square, \quad\left\langle\left(\begin{array}{llllll}
150 & 119 & 130 & 127 & 132 & 139
\end{array}\right) \rightarrow\right. \\
& \mathrm{i}=0 \\
& \text { “ } \mathrm{t} \square \mid \square \wedge\left(\begin{array}{llllll}
147 & 116 & 127 & 124 & 129 & \mathbf{1 3 6}
\end{array}\right) \rightarrow \\
& \mathrm{i}=1
\end{aligned}
$$

Hasil dekripsi baris pertama (i=1) akan digunakan sebagai chipertext pada proses dekripsi baris ke dua, sehingga :

$$
\begin{array}{rl}
\mathrm{i}=2 ; & \mathrm{j} \leq(6+1)-2 \\
\mathrm{M}_{21} & \mathrm{j} \leq 5 ; \\
& =\left(\mathrm{M}_{(2-1) 1}-\mathrm{K} *(\mathrm{R}[2])\right) \bmod 256 . \\
& =\left(\mathrm{M}_{(1) 1}-3 *(2)\right) \bmod 256 . \\
& =(“-6) \bmod 256 \\
& (147-6) \bmod 256 \\
& =141 \text { (huruf “ } \square \text { " dalam karakter }
\end{array}
$$

\begin{tabular}{|c|c|}
\hline$-\mathbf{w}, \square$, & (150 119 \\
\hline 132 139) & $\rightarrow \mathrm{i}=0$ \\
\hline $\begin{array}{l}\text { “ } \mathrm{t} \quad \square \mid \square \text { ^ } \\
129 \mathbf{1 3 6})\end{array}$ & $\begin{array}{l}(147 \quad 116 \\
\rightarrow \mathrm{i}=1\end{array}$ \\
\hline $\begin{array}{l}\square \mathrm{n} \text { y } \mathrm{v}\{ \\
123)\end{array}$ & $\begin{array}{l}(141 \quad 110 \\
\rightarrow \mathrm{i}=2\end{array}$ \\
\hline
\end{tabular}

$$
\begin{aligned}
\mathrm{M}_{22} & =\left(\mathrm{M}_{(2-1) 2}-\mathrm{K} *(\mathrm{R}[2])\right) \bmod 256 . \\
& =\left(\mathrm{M}_{(1) 2}-3 *(2)\right) \bmod 256 . \\
& =(\mathrm{t}-6) \bmod 256 \\
& =(116-6) \bmod 256 \\
& =110 \text { (huruf “ } \mathrm{n} \text { " dalam karakter }
\end{aligned}
$$
ASCII 256)

$\mathrm{M}_{23}=\left(\mathrm{M}_{(2-1) 3}-\mathrm{K} *(\mathrm{R}[2])\right) \bmod 256$.

$=\left(\mathrm{M}_{(1) 3}-3 *(2)\right) \bmod 256$.

$=(\square-6) \bmod 256$

$=(127-6) \bmod 256$

$=121$ (huruf " $\mathrm{y}$ " dalam karakter

ASCII 256)

$\mathrm{M}_{24}=\left(\mathrm{M}_{(2-1) 4}-\mathrm{K} *(\mathrm{R}[2])\right) \bmod 256$.

$=\left(\mathrm{M}_{(1) 4}-3 *(2)\right) \bmod 256$.

$=(\mid-6) \bmod 256$

$=(124-6) \bmod 256$ ASCII 256)

$=118$ (huruf “ $\mathrm{v}$ " dalam karakter

$\mathrm{M}_{25}=\left(\mathrm{M}_{(2-1) 5}-\mathrm{K} *(\mathrm{R}[2])\right) \bmod 256$.

$=\left(\mathrm{M}_{(1) 5}-3 *(2)\right) \bmod 256$.

$=(\square-6) \bmod 256$

$=(129-6) \bmod 256$

$=123$ (huruf “ $\{$ ” dalam karakter

ASCII 256)

hasil dari dekripsi baris ke dua $(\mathrm{i}=2)$ adalah

$\mathrm{n}$ y $\mathrm{v}\{$.

Hasil dekripsi sampai pada tahap baris ke dua $(i=$ 2) dapat dilihat di bawah ini :

Hasil dekripsi baris ke dua (i=2) akan digunakan sebagai chipertext pada proses dekripsi baris ke tiga, sehingga :

$$
\begin{array}{rl}
\mathrm{i}=3 ; & \mathrm{j} \leq(6+1)-3 \\
\mathrm{M}_{31} & \mathrm{j} \leq 4 ; \\
& =\left(\mathrm{M}_{(3-1) 1}-\mathrm{K} *(\mathrm{R}[3])\right) \bmod 256 . \\
& =\left(\mathrm{M}_{(2) 1}-3 *(3)\right) \bmod 256 . \\
& =(\square-9) \bmod 256 \\
& =(141-9) \bmod 256 \\
& =132 \text { (huruf "," " dalam karakter }
\end{array}
$$

ASCII 256)

$$
\begin{aligned}
\mathrm{M}_{32} & =\left(\mathrm{M}_{(3-1) 2}-\mathrm{K} *(\mathrm{R}[3])\right) \bmod 256 . \\
& =\left(\mathrm{M}_{(2) 2}-3 *(3)\right) \bmod 256 . \\
& =(\mathrm{n}-9) \bmod 256 \\
& =(110-9) \bmod 256 \\
& =101 \text { (huruf " } \mathrm{e} \text { " dalam karakter }
\end{aligned}
$$

ASCII 256)

$$
\begin{aligned}
\mathrm{M}_{33} & =\left(\mathrm{M}_{(3-1) 3}-\mathrm{K} *(\mathrm{R}[3])\right) \bmod 256 . \\
& =\left(\mathrm{M}_{(2) 3}-3 *(3)\right) \bmod 256 . \\
& =(\mathrm{y}-9) \bmod 256 \\
& =(121-9) \bmod 256 \\
& =112 \text { (huruf “ } \mathrm{p} \text { ” dalam karakter } \\
\text { ASCII 256) } & =\left(\mathrm{M}_{(3-1) 4}-\mathrm{K} *(\mathrm{R}[3])\right) \bmod 256 . \\
\mathrm{M}_{34} & =\left(\mathrm{M}_{(2) 4}-3 *(3)\right) \bmod 256 .
\end{aligned}
$$

Díterbitkan Oleh : STMIK Budí Darma Medan 


$$
\begin{aligned}
& =(\mathrm{v}-9) \bmod 256 \\
& =(118-9) \bmod 256 \\
& =109 \text { (huruf " } \mathrm{m} \text { " dalam karakter }
\end{aligned}
$$

ASCII 256)

hasil dari dekripsi baris ke dua $(i=2)$ adalah „epm .

Hasil dekripsi sampai pada tahap baris ke tiga $(\mathrm{i}=$ 3) dapat dilihat di bawah ini :

$$
\begin{aligned}
& \text { - w , } \square, \text { \& } \quad\left(\begin{array}{llll}
150 & 119 & 130 & 127
\end{array}\right. \\
& 132 \text { 139) } \rightarrow \mathrm{i}=0 \\
& \text { “ } \mathrm{t} \square \mid \square \wedge \quad(147 \quad 116 \quad 127 \quad 124 \\
& 129 \text { 136) } \rightarrow \mathrm{i}=1 \\
& \square \mathrm{n} \mathrm{y} \mathrm{v} \quad\left(\begin{array}{lllll}
141 & 110 & 121 & 118 & \mathbf{1 2 3}
\end{array}\right) \\
& \text {, e p m } \\
& \rightarrow \mathrm{i}=3
\end{aligned}
$$

Hasil dekripsi baris ke tiga $(i=3)$ akan digunakan sebagai chipertext pada proses dekripsi baris ke empat, sehingga :

$$
\begin{array}{rl}
\mathrm{i}=4 ; & \mathrm{j} \leq(6+1)-4 \\
\mathrm{M}_{41} & \mathrm{j} \leq 3 ; \\
& =\left(\mathrm{M}_{(4-1) 1}-\mathrm{K} *(\mathrm{R}[4])\right) \bmod 256 . \\
= & \left(\mathrm{M}_{(3) 1}-3 *(4)\right) \bmod 256 . \\
= & (,-12) \bmod 256 \\
= & (132-12) \bmod 256 \\
& =120 \text { (huruf “ } \mathrm{x} \text { " dalam karakter }
\end{array}
$$

ASCII 256)

$\mathrm{M}_{42}=\left(\mathrm{M}_{(4-1) 2}-\mathrm{K} *(\mathrm{R}[4])\right) \bmod 256$.

$=\left(\mathrm{M}_{(3) 2}-3 *(4)\right) \bmod 256$.

$=(\mathrm{e}-12) \bmod 256$

$=(101-12) \bmod 256$

$=89$ (huruf “ $\mathrm{Y}$ " dalam karakter ASCII 256)

$$
\begin{aligned}
\mathrm{M}_{43} & =\left(\mathrm{M}_{(4-1) 3}-\mathrm{K} *(\mathrm{R}[4])\right) \bmod 256 . \\
& =\left(\mathrm{M}_{(3) 3}-3 *(4)\right) \bmod 256 . \\
& =(\mathrm{p}-12) \bmod 256 \\
& =(112-12) \bmod 256 \\
& =100 \text { (huruf “ } \mathrm{d} \text { " dalam karakter }
\end{aligned}
$$

ASCII 256)

hasil dari dekripsi baris ke empat $(i=4)$ adalah xYd.

Hasil dekripsi sampai pada tahap baris ke empat (i $=4$ ) dapat dilihat di bawah ini :

$$
\begin{aligned}
& \begin{array}{lllll}
- \text { w }, \square, \text { < } & (150 & 119 & 130 & 127
\end{array} \\
& 132 \text { 139) } \rightarrow \mathrm{i}=0 \\
& \text { “ } \mathrm{t} \square \mid \square \text { ^ } \quad\left(\begin{array}{llll}
147 & 116 & 127 & 124
\end{array}\right. \\
& 129 \text { 136) } \rightarrow \mathrm{i}=1 \\
& \square \mathrm{n} \mathrm{y} \mathrm{v} \quad\left(\begin{array}{lllll}
141 & 110 & 121 & 118 & \mathbf{1 2 3}
\end{array}\right) \\
& \text {, e p m } \\
& \left(\begin{array}{llll}
132 & 101 & 112 & \mathbf{1 0 9}
\end{array}\right) \\
& \rightarrow \mathrm{i}=3 \\
& \text { x Y d } \quad\left(\begin{array}{lll}
120 & 89 & \mathbf{1 0 0}
\end{array}\right)
\end{aligned}
$$

Hasil dekripsi baris ke empat $(i=4)$ akan digunakan sebagai chipertext pada proses dekripsi baris ke lima, sehingga :

$$
\begin{array}{rlrl}
\mathrm{i}=5 ; & \mathrm{j} \leq(6+1)-5 \\
\mathrm{M}_{51} & & \mathrm{j} \leq 2 ; \\
& =\left(\mathrm{M}_{(5-1) 1}-\mathrm{K} *(\mathrm{R}[5])\right) \bmod 256 . \\
& =\left(\mathrm{M}_{(4) 1}-3 *(5)\right) \bmod 256 . \\
& =(120-15) \bmod 256 \\
&
\end{array}
$$
ASCII 256) $=105$ (huruf “ i " dalam karakter

$\mathrm{M}_{52}=\left(\mathrm{M}_{(5-1) 2}-\mathrm{K} *(\mathrm{R}[5])\right) \bmod 256$. $=\left(\mathrm{M}_{(4) 2}-3 *(5)\right) \bmod 256$.

$=(\mathrm{Y}-15) \bmod 256$

$=(89-15) \bmod 256$

$=74$ (huruf " $\mathrm{J}$ " dalam karakter ASCII

256)

hasil dari dekripsi baris ke empat $(i=5)$ adalah iJ .

Hasil dekripsi sampai pada tahap baris ke lima (i $=5$ ) dapat dilihat di bawah ini :

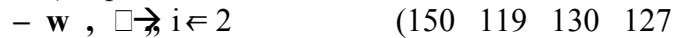

$$
\begin{aligned}
& 132 \text { 139) } \rightarrow \mathrm{i}=0 \\
& \text { “ } \mathrm{t} \square \mid \square \wedge \quad(147 \quad 116 \quad 127 \quad 124 \\
& 129 \text { 136) } \rightarrow \mathrm{i}=1 \\
& \square \mathrm{n} \mathrm{y} \mathrm{v} \quad\left(\begin{array}{lllll}
141 & 110 & 121 & 118 & \mathbf{1 2 3}
\end{array}\right) \\
& \text {, e p m } \rightarrow i=3 \\
& \left.\begin{array}{llll}
\text { x Y d } & (120 \quad 89 & \mathbf{1 0 0}
\end{array}\right) \\
& \text { i J (105 74) }
\end{aligned}
$$

Hasil dekripsi baris ke lima $(\mathrm{i}=5)$ akan digunakan sebagai chipertext pada proses dekripsi baris ke enam, sehingga :

$$
\begin{array}{rl}
\mathrm{i}=6 ; & \mathrm{j} \leq(6+1)-6 \\
\mathrm{M}_{61} & \mathrm{j} \leq 1 ; \\
& =\left(\mathrm{M}_{(6-1) 1}-\mathrm{K} *(\mathrm{R}[6])\right) \bmod 256 . \\
= & \left(\mathrm{M}_{(5) 1}-3 *(6)\right) \bmod 256 . \\
= & (\mathrm{i}-18) \bmod 256 \\
= & (105-18) \bmod 256 \\
= & 87 \text { (huruf “ W" dalam karakter }
\end{array}
$$

\section{ASCII 256)}

hasil dari dekripsi baris ke enam $(i=6)$ adalah W.

Hasil dekripsi sampai pada tahap baris ke enam (i =6) dapat dilihat di bawah ini :

$$
\begin{aligned}
& \text { “ } \mathrm{t} \square \mid \square \text { ^ } \\
& \left(\begin{array}{llll}
147 & 116 & 127 & 124
\end{array}\right. \\
& 129 \text { 136) } \rightarrow \mathrm{i}=1 ; \mathrm{j}=6 \\
& \square \mathrm{n} \mathrm{y} \mathrm{v \{} \mathrm{(141} 110121 \quad 118 \quad \mathbf{1 2 3}) \\
& \text {, e p m } \quad\left(\begin{array}{llll}
132 & 101 & 112 & \mathbf{1 0 9}
\end{array}\right) \\
& \left.\begin{array}{llll}
\mathrm{X} Y \mathbf{d} & (120 \quad 89 & \mathbf{1 0 0}
\end{array}\right) \\
& \text { i J } \quad\left(\begin{array}{ll}
105 & \mathbf{7 4}
\end{array}\right) \quad \rightarrow \text { i }=5 ; j=2 \\
& \text { W } \quad(87)
\end{aligned}
$$

sehingga pada proses dekripsi segitiga pertama diperoleh plainteks sesuai dengan formula $M_{i j}$ pada nilai $\mathrm{j}=(\mathrm{N}+\mathrm{i})-\mathrm{i}$ adalah $\mathbf{W J d m}\left\{{ }^{\wedge}\right.$.

2. Dekripsi sce gitiga ke dua

Proses dekripsi segitiga ke dua merupakan kebalikan dari hasil proses enkripsi segitiga pertama. $£$ lipetteks sumber adalah hasil akhir dari proses dekripsi segitiga pertama ( WJdm\{ ^ ).

Chipertext $=\mathbf{W} \quad \mathbf{J} \quad \mathbf{d} \quad \mathbf{m}\{\hat{\imath}$ (hasil dekrip pertama)

$$
\begin{array}{llllll}
87 & 74 & 100 & 109 & 123 & 136
\end{array}
$$

(nilai desimal dalam ASCII)

untuk baris pertama $(i=1)$ :

$$
\begin{aligned}
\mathrm{M}_{11} & =\mathrm{C}[1]-(3 * \mathrm{R}[1])) \bmod 256 \\
& =(\mathrm{W}-(3 * 1)) \bmod 256
\end{aligned}
$$




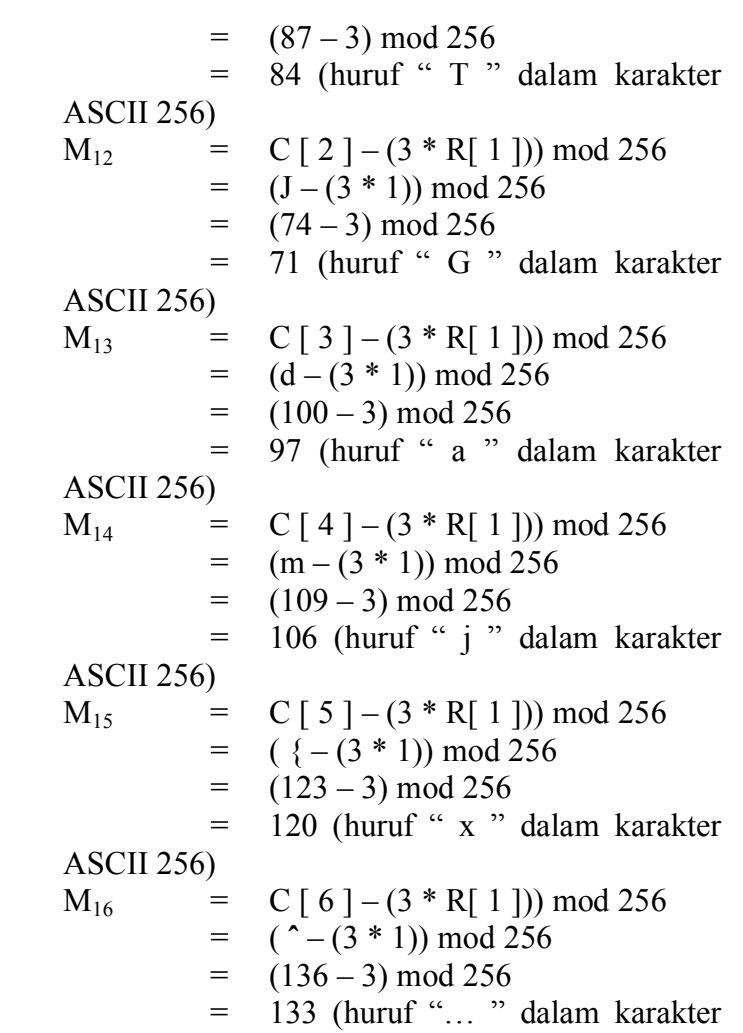

ASCII 256)

hasil dari dekripsi baris pertama $(i=1)$ adalah TGa jx ....

Hasil dekripsi sampai pada tahap baris pertama (i =1) dapat dilihat di bawah ini :

W J d m \{ ^ (dalam nilai ASCII 87 $\begin{array}{lllll}74 & 100 & 109 & 123 & 136)\end{array} \rightarrow \mathrm{i}=0$

T G a j $\mathbf{x} \ldots$

(dalam nilai ASCII 84

$\left.\begin{array}{lllll}71 & 97 & 106 & 120 & 133\end{array}\right)$

Hasil dekripsi baris pertama $(i=1)$ akan digunakan sebagai chipertext pada proses dekripsi baris ke dua, sehingga :

$\mathrm{i}=2 ; \mathrm{j} \geq 2$;

$\begin{aligned} \mathrm{M}_{22} & =\left(\mathrm{C}_{[2-1] 2}-(3 * \mathrm{R}[2])\right) \bmod 256 \\ & =\left(\mathrm{C}_{[1] 2}-(3 * 2)\right) \bmod 256 \\ & =(\mathrm{G}-6) \bmod 256 \\ & =(71-6) \bmod 256 \\ & =65 \text { (huruf " } \mathrm{A} \text { " dalam karakter }\end{aligned}$

ASCII 256)

$\mathrm{M}_{23}=\left(\mathrm{C}_{[2-1] 3}-(3 * \mathrm{R}[2])\right) \bmod 256$

$=\left(\mathrm{C}_{[1] 3}-(3 * 2)\right) \bmod 256$

$=(\mathrm{a}-6) \bmod 256$

$=(97-6) \bmod 256$

$=91$ (huruf " [ " dalam karakter

ASCII 256)

$\mathrm{M}_{24}=\left(\mathrm{C}_{[2-1] 4}-(3 * \mathrm{R}[2])\right) \bmod 256$

$=\left(\mathrm{C}_{[1] 4}-(3 * 2)\right) \bmod 256$

$=(\mathrm{j}-6) \bmod 256$

$=(106-6) \bmod 256$

$=100$ (huruf " $\mathrm{d}$ " dalam karakter

ASCII 256)

$\mathrm{M}_{25}=\left(\mathrm{C}_{[2-1] 5}-(3 * \mathrm{R}[2])\right) \bmod 256$
$=\left(\mathrm{C}_{[1] 5}-(3 * 2)\right) \bmod 256$

$=(\mathrm{x}-6) \bmod 256$

$=(120-6) \bmod 256$

$=114$ (huruf " $\mathrm{r}$ " dalam karakter

ASCII 256)

$\mathrm{M}_{26}=\left(\mathrm{C}_{[2-1] 6}-(3 * \mathrm{R}[2])\right) \bmod 256$

$=\left(\mathrm{C}_{[1] 6}-(3 * 2)\right) \bmod 256$

$=(\ldots-6) \bmod 256$

$=(133-6) \bmod 256$

$=127$ (huruf “ $\square$ " dalam karakter

ASCII 256)

hasil dari dekripsi baris pertama $(i=1)$ adalah A [ $\mathrm{d}$ r $\square$

Hasil dekripsi sampai pada tahap baris pertama (i =1) dapat dilihat di bawah ini :

W J d m \{ (dalam nilai ASCII 87 $\begin{array}{lllll}74 & 100 & 109 & 123 & 136) \rightarrow \mathrm{i}=0\end{array}$

T G a j $\mathbf{x} \ldots$ (dalam nilai ASCII 84 $\begin{array}{lllll}71 & 97 & 106 & 120 & 133)\end{array}$

A [ d r $\square$ (dalam nilai ASCII $\begin{array}{lllll}65 & 91 & 100 & 114 & 127)\end{array}$

Hasil dekripsi baris ke dua $(\mathrm{i}=2)$ akan digunakan sebagai chipertext pada proses dekripsi baris ke tiga, sehingga :

$\mathrm{i}=3 ; \mathrm{j} \geq 3$;

$\mathrm{M}_{33}=\left(\mathrm{C}_{[3-1] 3}-(3 * \mathrm{R}[3])\right) \bmod 256$

$=\left(\mathrm{C}_{[2] 3}-(3 * 3)\right) \bmod 256$

$=([-9) \bmod 256$

$=(91-9) \bmod 256$

$=82$ (huruf " $\mathrm{R}$ ” dalam karakter

ASCII 256)

$\mathrm{M}_{34}=\left(\mathrm{C}_{[3-1] 4}-(3 * \mathrm{R}[3])\right) \bmod 256$

$=\left(\mathrm{C}_{[2] 4}-(3 * 3)\right) \bmod 256$

$=(\mathrm{d}-9) \bmod 256$

$=(100-9) \bmod 256$

$=91$ (hurur $\mathrm{i}^{*}=[1$ " dalam karakter

ASCII 256)

$\mathrm{M}_{35}=\left(\mathrm{C}_{[3-1] 5}-(3 * \mathrm{R}[3])\right) \bmod 256$

$=\left(\mathrm{C}_{[2] 5}-(3 * 3)\right) \bmod 256$

$=(\mathrm{r}-9) \bmod 256$

$=(114-9) \bmod 256$

$=105$ (huruf “ $\mathrm{i}$ ” dalam karakter

ASCII 256)

$\mathrm{M}_{36}=\left(\mathrm{C}_{[3-1] 6}-(3 * \mathrm{R}[3])\right) \bmod 256$

$=\left(\mathrm{C}_{[2] 6}-(3 * 3)\right) \bmod 256$

$=(\square-9) \bmod 256$

$=(127-9) \bmod 256$

ASCII 256)

$=118$ (huruf " $\mathrm{v}$ " dalam karakter hasil dari dekripsi baris ke tiga $(\mathrm{i}=3)$ adalah $\mathbf{R}$ I i v

Hasil dekripsi sampai pada tahap baris ke tiga ( $\mathrm{i}=$ 3) dapat dilihat di bawah ini :

W J d m \{ (dalam nilai ASCII 87 $\begin{array}{lllll}74 & 100 & 109 & 123 & 136) \rightarrow \mathrm{i}=0\end{array}$

T G a j x ... (dalam nilai ASCII 84 $\begin{array}{lllll}71 & 97 & 106 & 120 & 133)\end{array}$

A $[\mathrm{d}$ r $\square$

(dalam nilai ASCII 
$\left.\begin{array}{lllll}65 & 91 & 100 & 114 & 127\end{array}\right)$

$\begin{array}{ll}\mathbf{R}[\mathrm{i} \mathrm{v} & \text { (dalam nilai } \\ 91105 \text { ASCII }\end{array}$

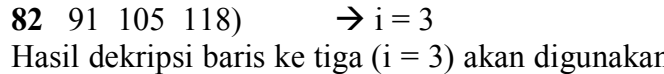
sebagai chipertext pada proses dekripsi baris ke empat, sehingga :

$\mathrm{i}=4 ; \mathrm{j} \geq 4$;

$$
\begin{aligned}
\mathrm{M}_{44} & =\left(\mathrm{C}_{[4-1] 4}-(3 * \mathrm{R}[4])\right) \bmod 256 \\
& =\left(\mathrm{C}_{[3] 4}-(3 * 4)\right) \bmod 256 \\
& =([-12) \bmod 256 \\
& =(91-12) \bmod 256 \\
& 79 \text { (huruf "O } \mathrm{O} \text { dalam karakter } \\
\text { ASCII 256) } & \\
\mathrm{M}_{45} & \left(\mathrm{C}_{[4-1] 5}-(3 * \mathrm{R}[4])\right) \bmod 256 \\
& =\left(\mathrm{C}_{[3] 5}-(3 * 4)\right) \bmod 256 \\
& =(\mathrm{i}-12) \bmod 256 \\
& =(105-12) \bmod 256 \\
& =93 \text { (huruf “]" dalam karakter }
\end{aligned}
$$

Hasil dekripsi sampai pada tahap baris ke empat (i =4) dapat dilihat di bawah ini :

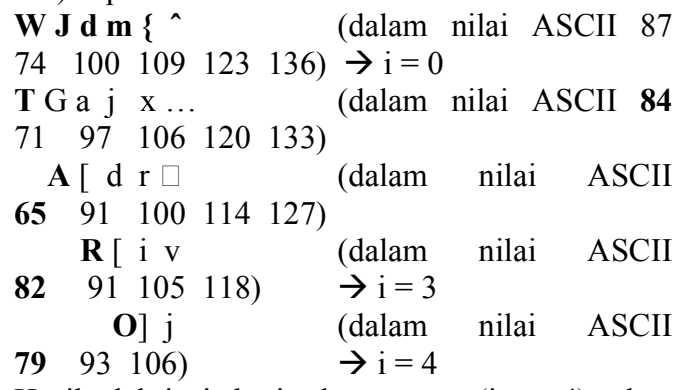

Hasil dekripsi baris ke empat $(i=4)$ akan digunakan sebagai chipertext pada proses dekripsi baris ke lima, sehingga :

$\mathrm{i}=5 ; \mathrm{j} \geq 5$;

$$
\begin{aligned}
\mathrm{M}_{55} & =\left(\mathrm{C}_{[5-1] 5}-(3 * \mathrm{R}[5])\right) \bmod 256 \\
& =\left(\mathrm{C}_{[4] 5}-(3 * 5)\right) \bmod 256 \\
& =(\mathrm{J}-15) \bmod 256 \\
& =78 \text { (huruf “ } \mathrm{N} \text { " dalam karakter } \\
\text { ASCII 256) } & \\
\mathrm{M}_{56} & \left(\mathrm{C}_{[5-1] 6}-(3 * \mathrm{R}[5])\right) \bmod 256 \\
& =\left(\mathrm{C}_{[4] 6}-(3 * 5)\right) \bmod 256 \\
& =(\mathrm{j}-15) \bmod 256 \\
& =(106-15) \bmod 256 \\
& =91 \text { (huruf “ }[\text { "dalam karakter }
\end{aligned}
$$

hasil dari dekripsi baris ke lima $(i=5)$ adalah N[ Hasil dekripsi sampai pada tahap baris ke lima (i $=5$ ) dapat dilihat di bawah ini :

W J d m \{ (dalam nilai ASCII 87

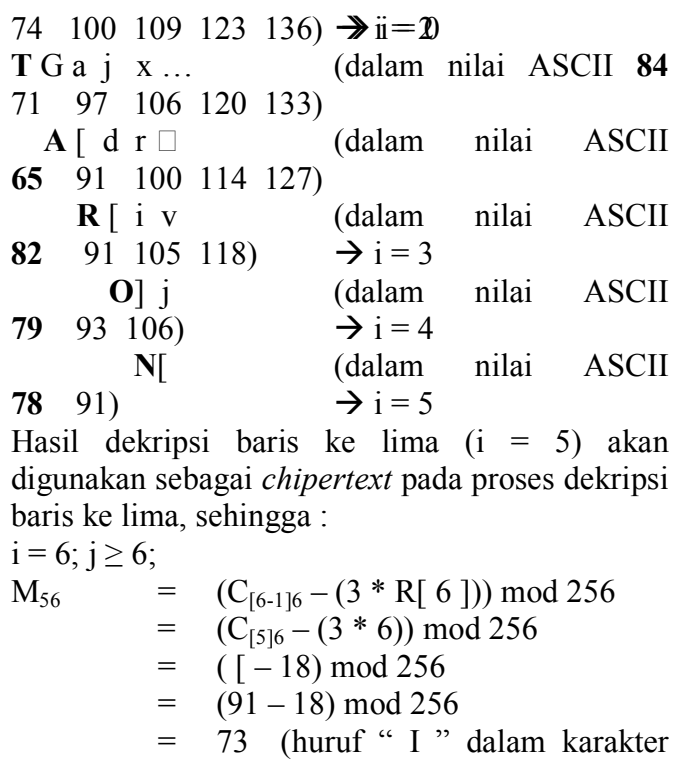
digunakan sebagai chipertext pada proses dekripsi baris ke lima, sehingga :

$\mathrm{i}=6 ; \mathrm{j} \geq 6$;

$$
\begin{aligned}
\mathrm{M}_{56} & =\left(\mathrm{C}_{[6-1] 6}-(3 * \mathrm{R}[6])\right) \bmod 256 \\
& =\left(\mathrm{C}_{[5] 6}-(3 * 6)\right) \bmod 256 \\
& =([-18) \bmod 256 \\
& =(91-18) \bmod 256
\end{aligned}
$$$$
=73 \text { (huruf " I " dalam karakter }
$$

ASCII 256)

hasil dari dekripsi baris ke enam $(i=6)$ adalah $I$ Hasil dekripsi sampai pada tahap baris ke enam (i $=6$ ) dapat dilihat di bawah ini :

W J d m \{ ^ (dalam nilai ASCII $87 \quad 74 \quad 100$ 109123 136) $\quad \rightarrow \mathrm{i}=0$

T G a j $\quad x \quad \ldots \quad$ (dalam nilai ASCII $84 \quad 71 \quad 97$ $106120133) \quad \rightarrow \mathrm{i}=1$

$\mathbf{A}[\mathrm{d} \mathrm{r} \square \quad$ (dalam nilai ASCII $\quad 65$ $\mathrm{M}_{\mathrm{ij}}$ pada nilai $\mathrm{j}=(\mathrm{N}+\mathrm{i})-\mathrm{N}$ pada masing-masing baris. Sehingga didapatkan plaintext adalah TARONI (sama seperti teks aslinya).

\section{Kesimpulan}

Setelah melakukan analisa terhadap penerapan algoritma triangle chain pada penyandian record database, maka penulis dapat menarik beberapa kesimpulan sebagai berikut :

1. Algoritma triangle chain melakukan proses penyandian pada setiap record dari tabel database yang telah dipilih sebanyak dua kali (secara ganda) dimana nilai subtitusi setiap karakter record tergantung pada nilai hasil perkalian kunci dengan bilangan faktor pengali yang terbentuk. Hasil akhir yang digunakan adalah hasil proses penyandian segitiga kedua dimana hasilnya tidak memiliki kemiripan dengan record asli. 
Pembentukan bilangan faktor pengali dalam proses penyandian dapat menggunakan bilangan integer positif, prima positif, ataupun bilangan yang dapat ditentukan sendiri oleh penggun, sehingga mampu mempersulit pemecahan sandi yang dihasilkan.

2. Implementasi penyandian record database diawali dengan penentuan nama database dan pemilihan tabel yang memiliki record yang disandikan. Masing-masing record pada tabel yang telah dipilih disandikan berdasarkan algoritma triangle chain yang telah tersedia di dalam aplikasi yang telah dibuat.

\section{Daftar Pustaka}

[1]. Doni Ariyus, 2008, Pengantar Ilmu Kriptografi, Yogyakarta, Andi.

[2]. Rinaldi Munir, 2006, Kriptografi, Bandung, Informatika..

[3]. http://informatika.stei.itb.ac.id/ rinaldi.munir/Kri ptografi/2006-2007/Makalah1/Makalah1-088.pdf.

[4]. http://id.wikipedia.org/wiki/Analisis

[5]. Janner Simarmata, Iman Paryudi 2005, Basis Data, Yogyakarta, Andi. 